\title{
Polyphenolics, Ascorbic Acid, and Soluble Solids Concentrations of Strawberry Cultivars and Selections Grown in a Winter Annual Hill Production System
}

\author{
David Del Pozo-Insfran, Christopher E. Duncan, Kristine C. Yu, and Stephen T. Talcott ${ }^{1}$ \\ Department of Food Science and Human Nutrition, University of Florida, P.O. Box 110370, Gainesville, \\ FL 32611-0370 \\ Craig K. Chandler \\ Gulf Coast Research and Education Center, University of Florida, Dover, FL 33527
}

AdDitional INDEX WORDS. Fragaria $\times$ ananassa, harvest season, antioxidant capacity

\begin{abstract}
The effects of cultivar, harvest date, and production year on the soluble solids and antioxidant phytochemical levels of 22 strawberry (Fragaria xananassa Duch.) genotypes grown in a winter annual hill (raised bed) production system were investigated. Fruit harvested in Jan. 2003 and 2004 were characterized by low polyphenolic content, but high concentrations of soluble solids and ascorbic acid; whereas fruit harvested in Feb. 2003 and 2004 generally had elevated polyphenolic concentrations, but lower levels of soluble solids and ascorbic acid. Annual variation in soluble solids and phytochemical composition was also observed among nine strawberry genotypes, which was likely attributable to variations in solar radiation and air temperature. 'Earlibrite' was among the highest for soluble solids concentration on three of the four harvest dates, while 'Carmine' was noted for its high phytochemical concentrations across harvest dates and years. The breeder selection 'FL 99-117' emerged as a promising selection in terms of producing fruit with high concentrations of soluble solids and antioxidant phytochemicals.
\end{abstract}

Strawberry is a nonclimacteric fruit that contains appreciable amounts of antioxidant phytochemicals and a highly desirable flavor (Ayala-Zavala et al., 2004; Perez et al., 1997). Florida is the second largest producer of fresh market strawberries in the United States (U.S. Dept. of Agriculture, 2004), and is the principal supplier of strawberries to eastern and midwestern U.S. and Canadian cities during December, January, and February. The University of Florida's Gulf Coast Research and Education Center near Tampa has an active strawberry breeding program that develops cultivars adapted to subtropical winter production areas. Chandler et al. (2003) recently noted that there are times during the winter production season in Florida when fruit of certain cultivars taste quite acidic, and suggested this may be partly due to low sugar levels caused by cloudy or warm weather or excessive crop loads. Consumer satisfaction for small fruit such as strawberries is highly dependent on sweetness (Darbellay et al., 2002), which is related to soluble solids content. Like flavor, antioxidant phytochemicals can vary among cultivars, and can be affected by environmental factors such as ultraviolet (UV) light exposure (Asami et al., 2003), plant growth temperature (Wang et al., 2002), geographic origin (Häkkinen et al., 1999), and soil moisture conditions (Anderson and Gorbet, 2002), among others.

The objective of this study was to assess the soluble solids, anthocyanins, phenolic acids, flavonoids, L-ascorbic acid, and antioxidant content of various strawberry cultivars and advanced breeding selections grown in a winter annual hill production sys-

Received for publication 31 May 2005. Accepted for publication 14 Aug. 2005 This research was supported in part by the Florida Fruit and Vegetable Research and Education Foundation and the Florida Agricultural Experiment Station, and approved for publication as Journal Series No. R-10854.

${ }^{1}$ To whom correspondence should be addressed; telephone: (352) 392-1991; fax: (352) 392-9467; e-mail: sttalcott@mail.ifas.ufl.edu tem. Results of this study will be used to help identify strawberry genotypes with fruit that are both consistently flavorful and high in health-promoting compounds, thus making them more desirable to consumers.

\section{Materials and Methods}

Harvest and Storage Conditions. Twenty-two strawberry genotypes (nine cultivars and 13 selections) were evaluated in 2003. A subset of the most abundant genotypes (five cultivars and four selections) was again evaluated in 2004 in order to investigate year-to-year variation in strawberry soluble solids and phytochemical levels.

The genotypes were grown in an annual hill cultural system at the Gulf Coast Research and Education Center at Dover, Fla. ( $25 \mathrm{~km}$ east of Tampa, Fla., at $28^{\circ} \mathrm{N}$ latitude), which is within the main commercial strawberry production area of the state. Plantings were made in field plots in October of each year and standard cultural practices followed throughout the season as described by Maynard and Olson (2000). Mature fruit (three-quarters to full red) were harvested on $23 \mathrm{Jan}$. and again on $27 \mathrm{Feb}$. in 2003 and 2004. Harvested fruit were held in a walk-in cooler at 2 ${ }^{\circ} \mathrm{C}$ for up to $24 \mathrm{~h}$ before being transported to the Food Science and Human Nutrition Department at the University of Florida's main campus in Gainesville. From a large pool $(\sim 750 \mathrm{~g})$ of ripe fruit with full red color, three replicates of six fruit each $(\sim 150$ g) were randomly collected and stored in individual reclosable, plastic bags of $0.1-\mathrm{mm}$ thickness at $-20{ }^{\circ} \mathrm{C}$. To minimize oxidase enzymes, frozen fruit were homogenized into a puree in a kitchen-scale food processor (Faberware, Bronx, N.Y.) for $1 \mathrm{~min}$ at $20^{\circ} \mathrm{C}$ and held on ice prior to obtaining samples for extraction and analysis. Random subsamples were analyzed within $15 \mathrm{~d}$ of frozen storage. 
Physicochemical analyses. Soluble solids and $\mathrm{pH}$ were measured directly from the thawed puree using a temperature auto-controlled digital Abbe Mark II refractometer (Reichert, Depew, N.Y.) and a Thermo Orion Model 720 pH meter (Thermo Electron Corp., New Haven, Conn.). Extractions for L-ascorbic acid measurements were conducted by homogenizing the fruit with $3 \%$ citric acid $(2 \mathrm{~g} / 10 \mathrm{~mL})$ for $25 \mathrm{~s}$ at maximum speed in a $50-\mathrm{mL}$ screw cap centrifuge tube (Brinkman Instruments, Westbury, N.Y.). Filtered isolates were then passed through preconditioned Waters $\mathrm{C}_{18}$ Sep-Pak cartridges (Waters, Milford, Mass.) to remove neutral polyphenolics, and after discarding the first milliliter, an aliquot was collected and filtered through a 0.45 $\mu \mathrm{m}$ polytetrafluoroethylene (PTFE) filter (Millipore, Bedford, Mass.) for high-performance liquid chromatography (HPLC) analysis. L-ascorbic acid was determined using modified chromatographic conditions described by Gökmen et al. (2000) using a Waters Alliance 2695 HPLC system equipped with a Waters 996 photodiode array detector (PDA). Separation was performed on a Supelcosil LC-18 column (Supelco, Bellefonte, Pa.) $(4.6 \times$ $250 \mathrm{~mm})$, using $\mathrm{KH}_{2} \mathrm{PO}_{4}(0.2 \mathrm{M}$, pH 2.4) as the mobile phase at a flow rate of $0.5 \mathrm{~mL} \cdot \mathrm{min}^{-1}$ with UV detection at $254 \mathrm{~nm}$ using a Waters 996 PDA detector.

For remaining chemical analyses, fruit puree was homogenized in methanol acidified with $0.01 \% \mathrm{HCl}(3 \mathrm{~g} / 10 \mathrm{~mL})$ and then filtered through Whatman \#4 filter paper. From these isolates determinations were made for anthocyanins, flavonoids, and phenolic acids using HPLC; total anthocyanins and total soluble phenolics using spectrophotometric assays; and finally antioxidant capacity using a fluorescent microplate reader. All data were expressed on a fresh weight basis.

Anthocyanin aglycones were quantified according to the HPLC conditions of Skrede et al. (2000) using a Dionex HPLC system (Dionex Corp., Sunnyvale, Calif.) and a Dionex PDA 100 detector. Compounds were separated on a $250 \times 4.6 \mathrm{~mm}$ Supelcosil LC-18 column and quantified using a cyanidin standard (Polyphenols Laboratories AS, Sandnes, Norway). Proper anthocyanin identification was confirmed based on PDA spectral interpretation from 200 to $600 \mathrm{~nm}$, retention time, and comparison with authentic standards (Polyphenols Laboratories AS). The anthocyanin contents of fruit harvested in 2003 and 2004 were compared using a pH differential method described by Wrolstad (1976) with data reported in pelargonidin 3-glucoside equivalents.

Flavonoids and phenolic acids were characterized and quantified on the Dionex HPLC system using modified chromatographic conditions of Talcott and Lee (2002) following acid hydrolysis into their respective aglycones $(2 \mathrm{~N} \mathrm{HCl}$ in $50 \% \mathrm{v} / \mathrm{v}$ methanol, 75 min at $90^{\circ} \mathrm{C}$ ). Separations were performed on a Dionex Acclaim $120-\mathrm{C}_{18}$ column $(250 \mathrm{~mm} \times 4.6 \mathrm{~mm})$ with a $\mathrm{C}_{18}$ guard column. Mobile phases consisted of water (phase A) and 60\% methanol (phase B), both adjusted to $\mathrm{pH} 2.4$ with $o$-phosphoric acid. A gradient solvent program ran phase B from $0 \%$ to $30 \%$ in $3 \mathrm{~min}$, $30 \%$ to $50 \%$ in $5 \mathrm{~min}, 50 \%$ to $70 \%$ in $17 \mathrm{~min}, 70 \%$ to $80 \%$ in 5 min, and $80 \%$ to $100 \%$ in $5 \mathrm{~min}$, and held for $10 \mathrm{~min}$ all at 0.8 $\mathrm{mL} \cdot \mathrm{min}^{-1}$. The following polyphenolics were identified by spectral interpretation, retention time, and comparison to authentic standards (Sigma Chemical Co., St. Louis): ellagic acid, caffeic acid, chlorogenic acid, and $p$-coumaric acid.

Total soluble phenolics, including contributions from ascorbic acid, were measured using the Folin-Ciocalteu assay with modifications as described by Talcott et al. (2000) with data expressed as gallic acid equivalents. Antioxidant capacity was determined using the oxygen radical absorbance capacity (ORAC) assay evaluated against a standard of Trolox as described by Talcott et al. (2003). Isolates were diluted 10 -fold in $\mathrm{pH} 7.0$ phosphate buffer prior to pipetting into a 96-well microplate with corrections made for background interference due to the phosphate buffer and extraction solvent.

Statistical anAlYsis. Analyses of variances (ANOVA) were performed with genotypes and harvest date (January or February) as fixed effects, and years and extracts as random effects. Years were nested within harvest dates, and extracts nested within genotypes. Data represent the mean of three replicates. Multiple linear regression, Pearson correlation coefficients, and analysis of variance were conducted using JMP software (version 5; SAS Institute, Cary, N.C.), with mean separation performed by the least significant difference (LSD) test $(P<0.05)$.

\section{Results and Discussion}

The flavor of fresh strawberries is highly dependent on both sweetness and aroma-active compounds. Unfortunately, both sensory attributes can vary significantly from harvest to harvest. Therefore, those genotypes adapted to winter production and whose fruit are consistently high in sugar, visually appealing, and provide a good source of antioxidant phytochemicals are most desirable for marketing or commercialization. Evaluation of phytochemicals in fruit and vegetables is important, not only for their color and flavor attributes, but also for their recognized role as potential health-promoting agents (Darbellay et al., 2002).

Independent of annual variation, fruit harvested on $23 \mathrm{Jan}$. had high soluble solids and ascorbic acid contents and low polyphenolic concentrations, while fruit harvested on $27 \mathrm{Feb}$. had lower soluble solids and ascorbic acid contents and high polyphenolic content. Across harvests, fruit weight ranged from 20 to $38 \mathrm{~g} /$ fruit and averaged $26 \pm 4 \mathrm{~g} /$ fruit. Despite observed variations in the amounts of individual antioxidant phytochemical compounds, when considered collectively their antioxidant activity was not significantly affected by harvest date within year. Variation in phytochemical content between years was also observed, and this variation may be related to yearly variation in solar radiation (i.e., cloud cover) and air temperature (Anderson and Gorbet, 2002; Asami et al., 2003; Häkkinen et al., 1999; Wang et al., 2002).

2003 Strawberry harvests. Phytochemical synthesis in strawberries is controlled by a combination of genetic and environmental factors; the latter could include light intensity and duration, soil fertility, and air temperature. January-harvested fruit developed during December and January when day length ranged from 10.4 to $10.9 \mathrm{~h}$ and mean air temperature was 11.4 ${ }^{\circ} \mathrm{C}$, with a range of -3 to $11.5^{\circ} \mathrm{C}$ (U.S. Naval Observatory, 2004; University of Florida, 2004). February-harvested fruit developed during January and February when day length ranged from 10.8 to $11.6 \mathrm{~h}$ and mean air temperature was $15.9^{\circ} \mathrm{C}$, with a range of 4 to $21^{\circ} \mathrm{C}$. Furthermore, average daily solar radiation was slightly less during the development period of fruit harvested on 23 Jan. than those harvested on $27 \mathrm{Feb}$. (640 vs. $672 \mu \mathrm{mol} \cdot \mathrm{m}^{-2} \cdot \mathrm{s}^{-1}$; University of Florida, 2004). The mean air temperature during the development period for fruit harvested on $23 \mathrm{Jan}$. was lower than the long-term mean air temperature for the research center site, while the mean air temperature during the development period for fruit harvested $27 \mathrm{Feb}$. was higher than the long-term mean air temperature for the research center site.

Anthocyanins are the pigments that give strawberries their red color, so they are important in terms of fruit appearance. However, 
they are also important because of their ability to scavenge various free radicals and therefore may possess health-promoting properties (Meyer et al., 1999, 2003). Anthocyanins were quantified by HPLC following acid hydrolysis into aglycones (Table 1), but fruit extracts were additionally characterized for the presence of glycosides. Although several glycosylated and acylated derivatives of pelargonidin and cyanidin have been reported in strawberries (Cordenunsi et al., 2005; Kosar et al., 2004; Meyers et al., 2003; Wang and Zheng, 2001), pelargonidin 3-glucoside was the most predominant anthocyanin with cyanidin 3-glucoside present in appreciably lower concentrations (Bridle and Garcia-Viguera, 1997; Hong and Wrolstad, 1990). Pelargonidin and cyanidin were present in all cultivars, but their levels varied considerably, ranging from 189 to $1093 \mathrm{mg} \cdot \mathrm{kg}^{-1}$ for pelargonidin and from 49 to $196 \mathrm{mg} \cdot \mathrm{kg}^{-1}$ for cyanidin (Table 1 ). Harvest date had a significant effect on anthocyanin levels with 1.4- to 2.8-fold higher levels for individual and total anthocyanins at the 27 Feb. harvest compared to the 23 Jan. harvest. 'Treasure' was consistently high in cyanidin whereas 'Carmine' had relatively high total anthocyanins on both harvest dates (Table 1). 'Treasure', 'Earlibrite', 'Carmine', and the breeder selection 'FL 99-56' contained the highest anthocyanin contents among the genotypes evaluated, with the highest concentrations in the February harvest. Insignificant differences in anthocyanins were observed between harvest dates for 'Gaviota', 'Treasure', 'Aromas', and the breeder selections 'FL 00-7', 'FL 95-269', 'FL 99-56', and 'FL 99-8'. Anthocyanin concentrations were generally in agreement with those found in other studies (Cordenunsi et al., 2005; Kosar et al., 2004; Meyers et al., 2003; Wang and Zheng, 2001). Environmental conditions are known to impact the biosynthesis of polyphenolics as part of a defense mechanism from various stress factors, such as pests, disease, and UV light exposure, suggesting a chemoprotective role in plants (Asami et al., 2003), while other additional studies indicate the role of light exposure, solar radiation, and number of daylight hours for their synthesis in small fruit (Kahkonen et al., 2001; Linko et al., 1983).

Aside from colorful anthocyanins that appeal to the visual senses, strawberries also contain other colorless phenolic acids that contribute to the antioxidant and quality attributes of the fruit. Large differences in polyphenolics, ascorbic acid, and antioxidant capacity among strawberry cultivars were previously reported (Olsson et al., 2004), with differences within cultivar attributable to air temperature. In the current study, phenolic acids were individually quantified for strawberries harvested in 2003, and when results were averaged across cultivars, those fruit harvested in February had a $23 \%$ higher concentration than fruit harvested

Table 1. Effect of harvest time on the pelargonidin (quantified by HPLC), cyandin (quantified by HPLC), and total anthocyanin (quantified using the $\mathrm{pH}$-differential assay) content of winter-grown strawberries grown in 2003. Data is expressed on a fresh weight basis (means \pm SE). Analysis of variance was also determined for the 22 cultivars harvested in 2003.

\begin{tabular}{|c|c|c|c|c|c|c|c|}
\hline \multirow[b]{2}{*}{ Cultivar } & & \multicolumn{3}{|c|}{ January harvest (2003) } & \multicolumn{3}{|c|}{ February harvest (2003) } \\
\hline & & Pelargonidin & Cyanidin & $\begin{array}{c}\text { Total } \\
\text { anthocyanins }\end{array}$ & Pelargonidin & Cyanidin & $\begin{array}{c}\text { Total } \\
\text { anthocyanins }\end{array}$ \\
\hline & & \multicolumn{6}{|c|}{ - } \\
\hline Aromas & & $431 \pm 30$ & $108 \pm 17$ & $453 \pm 21$ & $553 \pm 15$ & $124 \pm 2.3$ & $308 \pm 6.3$ \\
\hline Camarosa & & $468 \pm 37$ & $138 \pm 11$ & $339 \pm 9.9$ & $767 \pm 37$ & $133 \pm 4.9$ & $490 \pm 40$ \\
\hline Carmine & & $560 \pm 38$ & $116 \pm 13$ & $398 \pm 11$ & $850 \pm 5.8$ & $117 \pm 6.5$ & $535 \pm 37$ \\
\hline Earlibrite & & $614 \pm 170$ & $107 \pm 5.9$ & $241 \pm 14$ & $924 \pm 160$ & $120 \pm 2$ & $435 \pm 37$ \\
\hline Festival & & $440 \pm 34$ & $75.7 \pm 11$ & $280 \pm 37$ & $1030 \pm 27$ & $122 \pm 3.7$ & $548 \pm 26$ \\
\hline Gaviota & & $514 \pm 36$ & $110 \pm 10$ & $413 \pm 9.2$ & $727 \pm 37$ & $116 \pm 2.7$ & $427 \pm 36$ \\
\hline Rosa Linda & & $350 \pm 18$ & $56.9 \pm 3.1$ & $322 \pm 24$ & $1040 \pm 200$ & $98.0 \pm 1.7$ & $451 \pm 16$ \\
\hline Sweet Charlie & & $290 \pm 58$ & $48.7 \pm 7.2$ & $192 \pm 6.8$ & $640 \pm 64$ & $133 \pm 57$ & $350 \pm 25$ \\
\hline Treasure & & $457 \pm 36$ & $196 \pm 32$ & $345 \pm 14$ & $507 \pm 45$ & $174 \pm 12$ & $394 \pm 5.4$ \\
\hline $95-14$ & & $449 \pm 32$ & $131 \pm 13$ & $309 \pm 26$ & $736 \pm 110$ & $147 \pm 19$ & $372 \pm 21$ \\
\hline $95-269$ & & $262 \pm 23$ & $91.5 \pm 16$ & $258 \pm 5.9$ & $480 \pm 11$ & $102 \pm 4.6$ & $274 \pm 9.0$ \\
\hline $96-59$ & & $391 \pm 37$ & $72.8 \pm 10$ & $294 \pm 29$ & $958 \pm 2.2$ & $101 \pm 1.3$ & $551 \pm 4.3$ \\
\hline $97-39$ & & $489 \pm 16$ & $80.3 \pm 2.4$ & $346 \pm 15$ & $1090 \pm 103$ & $133 \pm 13$ & $512 \pm 21$ \\
\hline $97-83$ & & $304 \pm 67$ & $142 \pm 59$ & $200 \pm 21$ & $942 \pm 140$ & $185 \pm 15$ & $321 \pm 34$ \\
\hline $99-56$ & & $613 \pm 8.5$ & $99.5 \pm 6.8$ & $188 \pm 16$ & $797 \pm 63$ & $128 \pm 31$ & $301 \pm 10$ \\
\hline $99-8$ & & $448 \pm 28$ & $68.2 \pm 20$ & $237 \pm 9.0$ & $580 \pm 58$ & $81.3 \pm 7.2$ & $380 \pm 47$ \\
\hline $99-117$ & & $189 \pm 4.9$ & $55.0 \pm 7.5$ & $221 \pm 4.7$ & $1010 \pm 231$ & $161 \pm 21$ & $384 \pm 24$ \\
\hline $99-140$ & & $395 \pm 30$ & $90.9 \pm 9.4$ & $295 \pm 24$ & $699 \pm 22$ & $124 \pm 6.7$ & $419 \pm 13$ \\
\hline $99-164$ & & $406 \pm 59$ & $94.6 \pm 13$ & $355 \pm 20$ & $796 \pm 20$ & $164 \pm 2.0$ & $444 \pm 43$ \\
\hline $00-7$ & & $276 \pm 51$ & $89.2 \pm 22$ & $197 \pm 39$ & $411 \pm 13$ & $63.7 \pm 2.3$ & $242 \pm 41$ \\
\hline $00-45$ & & $504 \pm 77$ & $68.3 \pm 12$ & $385 \pm 25$ & $817 \pm 23$ & $120 \pm 1.8$ & $503 \pm 31$ \\
\hline $00-59$ & & $330 \pm 27$ & $110 \pm 22$ & $303 \pm 23$ & $929 \pm 24$ & $106 \pm 10$ & $516 \pm 13$ \\
\hline \multirow[t]{3}{*}{$\mathrm{LSD}_{0.05}$} & & 152.4 & 53.8 & 58.4 & 264 & 49.8 & 98.2 \\
\hline & & \multicolumn{2}{|c|}{ Pelargonidin } & \multicolumn{2}{|c|}{ Cyanidin } & \multicolumn{2}{|c|}{ Total anthocyanins } \\
\hline & df & Mean square & $\mathrm{F}$ & Mean square & $\mathrm{F}$ & Mean square & $\mathrm{F}$ \\
\hline$\overline{\text { Harvest }(\mathrm{H})}$ & 1 & 4427861 & $259^{* * * \mathrm{y}}$ & 24300 & $24.5^{* * *}$ & 454463 & $252^{* * *}$ \\
\hline Cultivar (C) & 21 & 17793072 & $4.96^{* * * *}$ & 91226 & $4.37^{* * *}$ & 665087 & $15.5^{* * * *}$ \\
\hline $\mathrm{H} \times \mathrm{C}$ & 21 & 1428559 & $3.98^{* * *}$ & 33776 & $1.62^{* * *}$ & 247589 & $6.52^{* * *}$ \\
\hline
\end{tabular}

${ }^{2}$ Total anthocyanin content was quantified with the $\mathrm{pH}$-differential, spectrophotometric assay (pelargonidin 3-glucoside equivalents). Ns, *,******Nonsignificant or significant at $P<0.05,0.01$, or 0.001 , respectively. 
in January (Tables 2 and 3). A similar trend was observed for total anthocyanins. The predominant phenolic acids present were chlorogenic acid (127-464 $\mathrm{mg} \cdot \mathrm{kg}^{-1}$ fruit) $>$ ellagic acid (81.2-164 $\left.\mathrm{mg} \cdot \mathrm{kg}^{-1}\right)>$ caffeic acid $\left(17.8-50.2 \mathrm{mg} \cdot \mathrm{kg}^{-1}\right)$, and $>p$-coumaric acid (1-5 $\left.\mathrm{mg} \cdot \mathrm{kg}^{-1}\right)$. These compounds were previously identified in various strawberry cultivars and at similar concentrations (Häkkinen et al., 1999; Olsson et al., 2004; Sanli et al., 2002; Wang and Zheng, 2001). Elevated concentrations of polyphenolics were reported by Wang and Camp (2000) due to warmer growing conditions, with a positive correlation between day/night temperatures and anthocyanin and polyphenolic concentrations, and a negative correlation between day/night temperatures and soluble solids, titratable acidity, and ascorbic acid content. Wang and Zheng (2001) also observed that fruit from plants grown in cooler climates generally had lower levels of phenolic acids, flavonols, and anthocyanins. Contrary to Wang and Camp (2000), the current study did not show a negative correlation between air temperature and free ellagic acid concentration. Invariability in free ellagic acid content likely accounted for the presence of other forms of ellagic acid, such as its glycosides and conjugates, which were likely synthesized in the plant as a result of environmental stress. Presence of these derivatives was accounted in the present study since isolates underwent acid hydrolysis previous to HPLC analysis. A similar trend was observed for raspberry jams
(Zafrilla et al., 2001) where increases in free ellagic acid content were apparently due to breakdown of ellagitannins during thermal treatments and storage.

Significant differences in L-ascorbic acid content were also observed among the various strawberry selections and cultivars and between harvests. January-harvested fruit contained higher concentrations (1.4- to 1.7-fold) than February-harvested fruit, in contrast to the trend for anthocyanins and phenolic acids. Lascorbic acid concentrations ranged from 220 to $339 \mathrm{mg} \cdot \mathrm{kg}^{-1}$ for fruit harvested in January, and from 136 to $257 \mathrm{mg} \cdot \mathrm{kg}^{-1}$ for fruit harvested in February (Table 3), with values in general agreement with previous studies (Asami et al., 2003; Gokmen et al., 2000; Kalt et al., 1999). 'Festival' and 'Treasure', currently the two most popular commercial cultivars in Florida, had high Lascorbic acid levels (298 and $339 \mathrm{mg} \cdot \mathrm{kg}^{-1}$, respectively) in their January fruit but levels in their February fruit were nearly $40 \%$ less (Table 3). The breeder selection 'FL 99-8', in contrast, had relatively high levels of L-ascorbic acid in both its January and February fruit (331 and $257 \mathrm{mg} \cdot \mathrm{kg}^{-1}$, respectively).

Despite the influence of harvest date on the concentration of individual antioxidant phytochemicals, harvest date did not have a significant effect on antioxidant capacity or total soluble phenolic concentrations. Since the Folin-Ciocalteu assay simultaneously detects all polyphenolics, ascorbic acid, reducing

Table 2. Effect of harvest time on total ellagic, $p$-coumaric, and chlorogenic acid concentrations of winter-grown strawberries harvested in 2003. Data is expressed on a fresh weight basis (mean $\pm \mathrm{SE}$ ). Analysis of variance was also determined for the 22 cultivars harvested in 2003.

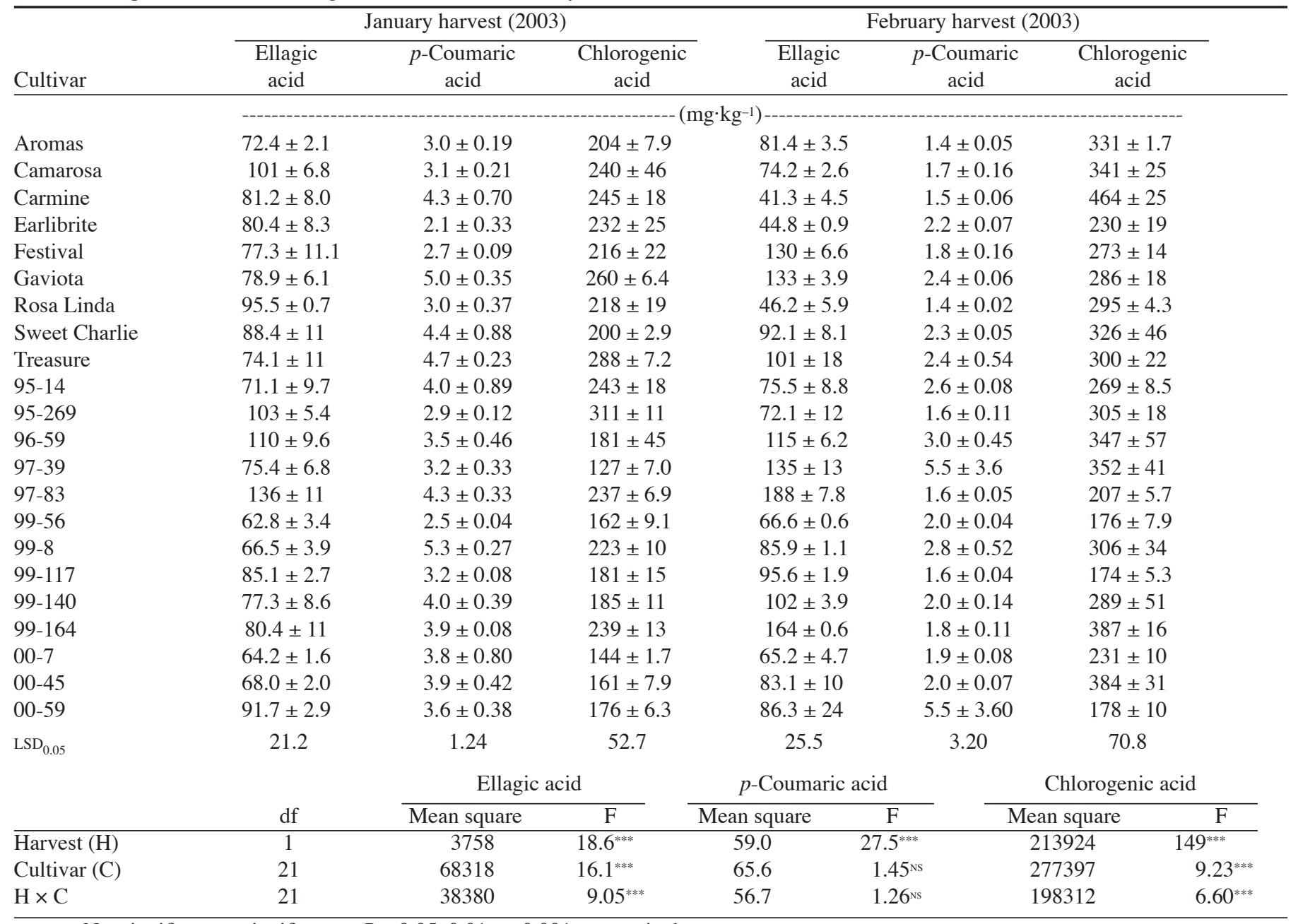

Ns, ${ }^{*}, * * * * *$ Nonsignificant or significant at $P<0.05,0.01$, or 0.001 , respectively. 
Table 3. Effect of harvest time on caffeic acid, total polyphenolics by HPLC, and L-ascorbic acid concentrations of winter-grown strawberries harvested in 2003. Data is expressed on a fresh weight basis (mean $\pm \mathrm{SE}$ ). Analysis of variance was also determined for the 22 cultivars harvested in 2003.

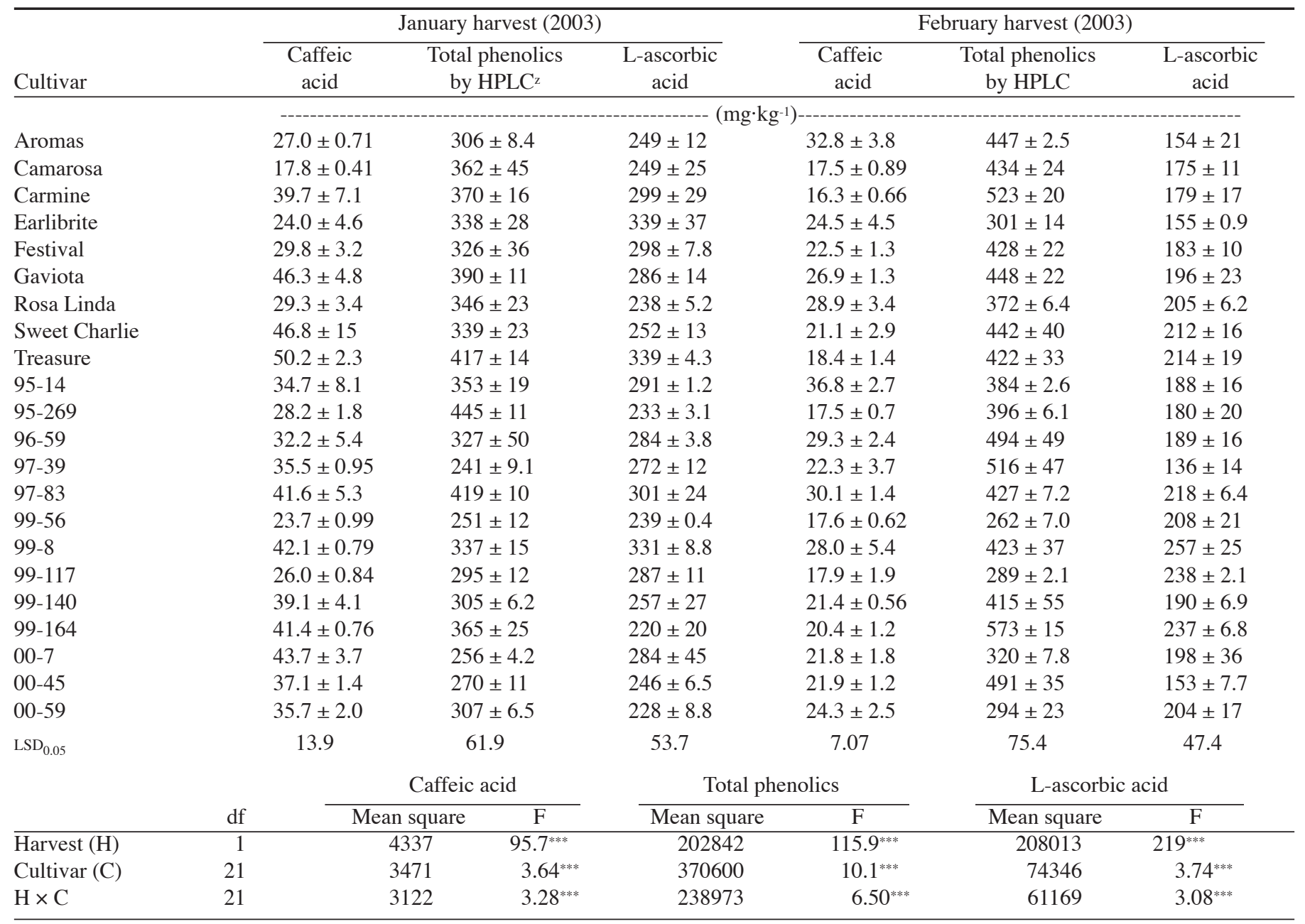

zTotal phenolic content is the sum of all quantified phenolic acids and flavonoids separated by HPLC. Ns,,$* * * * * *$ Nonsignificant or significant at $P<0.05,0.01$, or 0.001 , respectively.

sugars, and certain proteins, an overall lack of difference between harvest dates could be expected based on chemical composition. Individually, antioxidant phytochemicals have different radical scavenging responses when tested in vitro (Meyer et al., 1998; Pinelo et al., 2004; Rice-Evans et al., 1996; Sekher et al., 2001), creating a diversified matrix of compounds with varying peroxyl radical scavenging activities. Moreover, the effectiveness of an antioxidant compound is dependent on the polarity of the testing system, the nature of the radical, and type of substrate protected by the antioxidant (Rice-Evans et al., 1996; Sekher et al., 2001). For the strawberry genotypes evaluated, the diversity and potential interactions among antioxidant compounds were further complicated due to differences between harvest times. Antioxidant capacity varied significantly among genotypes, and ranged from 20.7 to $34.8 \mu \mathrm{M}^{\cdot} \mathrm{g}^{-1}$ Trolox equivalents for fruit harvested on 23 Jan., and from 20.1 to $37.9 \mu \mathrm{M}^{\cdot \mathrm{g}^{-1}}$ Trolox equivalents for fruit harvested on $27 \mathrm{Feb}$. (Table 4). Antioxidant capacity values were 1.5- to 3-fold higher than previously reported (Ayala-Zavala et al., 2004; Kalt et al., 1999; Wang and Lin, 2000a, 2000b; Wang and Zheng, 2001; Wang et al., 1996). This discrepancy may be attributable to cultivar, environmental, or specific analytical factors. Similar amounts of total soluble phenolics were observed among genotypes harvested on 23 Jan. and ranged from 772 to $1240 \mathrm{mg} \cdot \mathrm{kg}^{-1}$, which were similar to values previously reported for strawberries (Amakura et al., 2000; Asami et al., 2003; Wang and Lin, 2000a, 2000b).

Soluble solids concentration (\%) is a trait directly related to consumer acceptability of strawberry fruit, with fruit with high soluble solids generally more acceptable than fruit with low soluble solids (Chandler et al., 2003). Over the two production years, fruit harvested on $23 \mathrm{Jan}$. had higher levels of soluble solids than the fruit harvested on 27 Feb. (Table 4). For example, 'Festival' fruit harvested in January had an average soluble solids of $10.5 \%$ compared to $5.2 \%$ for fruit harvested on 27 Feb. These differences were readily detected in informal color and flavor sensory evaluations. The breeder selections 'FL 96-59', 'FL 97-83', and 'FL 99-117' had relatively high solids concentrations over the harvest times, a desirable trait to have in new cultivars. The $\mathrm{pH}$ of the fruit varied slightly among cultivars, ranging from $\mathrm{pH} 3.6$ to 4.0, but was unaffected by harvest date (data not shown).

2004 Strawberry HaRvests. Soluble solids, total polyphenolics, L-ascorbic aicd, and antioxidant capacity data were collected for nine of the 22 strawberry genotypes in 2004 (Table 5) as a means to determine year-to-year differences in quality and 
Table 4. Effect of harvest time on the antioxidant capacity, total soluble phenolic (Folin-Ciocalteu assay), and total soluble solids of winter-grown strawberries harvested in 2003. Data is expressed on a fresh weight basis (mean $\pm \mathrm{SE}$ ). Analysis of variance was also determined for the 22 cultivars harvested in 2003.

\begin{tabular}{|c|c|c|c|c|c|c|c|}
\hline \multirow[b]{2}{*}{ Cultivar } & & \multicolumn{3}{|c|}{ January harvest (2003) } & \multicolumn{3}{|c|}{ February harvest (2003) } \\
\hline & & $\begin{array}{c}\text { Antioxidant } \\
\text { capacity } \\
\left(\mu \mathrm{M} \cdot \mathrm{g}^{-1} \mathrm{TE}\right)\end{array}$ & $\begin{array}{c}\text { Total soluble } \\
\text { phenolics } \\
\left(\mathrm{mg} \cdot \mathrm{kg}^{-1}\right)\end{array}$ & $\begin{array}{c}\text { Total soluble } \\
\text { solids } \\
(\%)\end{array}$ & $\begin{array}{c}\text { Antioxidant } \\
\text { capacity } \\
\left(\mu \mathrm{M} \cdot \mathrm{g}^{-1} \mathrm{TE}\right)\end{array}$ & $\begin{array}{c}\text { Total soluble } \\
\text { phenolics } \\
\left(\mathrm{mg} \cdot \mathrm{kg}^{-1}\right)\end{array}$ & $\begin{array}{c}\text { Total soluble } \\
\text { solids } \\
(\%)\end{array}$ \\
\hline Aromas & & $29.0 \pm 0.38$ & $936 \pm 56$ & $8.67 \pm 0.93$ & $28.1 \pm 1.9$ & $911 \pm 21$ & $3.77 \pm 0.35$ \\
\hline Camarosa & & $30.5 \pm 3.09$ & $881 \pm 88$ & $9.80 \pm 0.44$ & $31.4 \pm 3.5$ & $1050 \pm 24$ & $5.13 \pm 0.43$ \\
\hline Carmine & & $33.6 \pm 0.94$ & $1110 \pm 46$ & $9.67 \pm 0.32$ & $33.9 \pm 0.9$ & $1240 \pm 51$ & $4.67 \pm 0.17$ \\
\hline Earlibrite & & $30.1 \pm 1.84$ & $1080 \pm 66$ & $10.2 \pm 0.24$ & $28.8 \pm 1.4$ & $1090 \pm 2$ & $4.87 \pm 0.03$ \\
\hline Festival & & $28.3 \pm 1.96$ & $810 \pm 88$ & $10.5 \pm 0.20$ & $29.3 \pm 1.1$ & $1000 \pm 86$ & $5.17 \pm 0.23$ \\
\hline Gaviota & & $24.7 \pm 0.20$ & $804 \pm 120$ & $8.63 \pm 0.22$ & $25.6 \pm 0.8$ & $998 \pm 56$ & $5.00 \pm 0.25$ \\
\hline Rosa Linda & & $32.7 \pm 1.90$ & $1060 \pm 110$ & $9.50 \pm 0.00$ & $30.3 \pm 2.5$ & $1100 \pm 50$ & $4.77 \pm 0.19$ \\
\hline Sweet Charlie & & $25.8 \pm 0.29$ & $781 \pm 48$ & $9.57 \pm 0.23$ & $26.9 \pm 1.2$ & $848 \pm 25$ & $4.93 \pm 0.38$ \\
\hline Treasure & & $28.3 \pm 1.96$ & $909 \pm 70$ & $9.07 \pm 0.33$ & $27.1 \pm 1.7$ & $866 \pm 13$ & $5.43 \pm 0.03$ \\
\hline $95-14$ & & $23.6 \pm 0.82$ & $832 \pm 61$ & $8.20 \pm 0.00$ & $26.6 \pm 2.2$ & $937 \pm 56$ & $4.83 \pm 0.12$ \\
\hline $95-269$ & & $32.2 \pm 2.30$ & $988 \pm 47$ & $9.07 \pm 0.19$ & $28.8 \pm 2.0$ & $930 \pm 13$ & $4.90 \pm 0.10$ \\
\hline $96-59$ & & $27.9 \pm 1.52$ & $1040 \pm 68$ & $9.23 \pm 0.39$ & $28.8 \pm 0.7$ & $992 \pm 36$ & $6.05 \pm 0.04$ \\
\hline $97-39$ & & $29.7 \pm 2.80$ & $942 \pm 43$ & $8.50 \pm 0.20$ & $28.5 \pm 2.6$ & $1040 \pm 48$ & $4.00 \pm 0.00$ \\
\hline $97-83$ & & $27.4 \pm 1.67$ & $1070 \pm 130$ & $10.2 \pm 0.12$ & $33.1 \pm 2.3$ & $1190 \pm 57$ & $6.07 \pm 0.18$ \\
\hline $99-56$ & & $20.7 \pm 1.43$ & $798 \pm 32$ & $8.93 \pm 0.24$ & $23.9 \pm 0.8$ & $890 \pm 62$ & $5.23 \pm 0.18$ \\
\hline $99-8$ & & $24.7 \pm 1.56$ & $840 \pm 73$ & $10.3 \pm 0.19$ & $20.1 \pm 5.2$ & $974 \pm 74$ & $5.23 \pm 0.24$ \\
\hline $99-117$ & & $34.8 \pm 3.41$ & $1050 \pm 120$ & $10.3 \pm 0.26$ & $32.8 \pm 1.0$ & $1190 \pm 46$ & $5.90 \pm 0.21$ \\
\hline $99-140$ & & $25.9 \pm 1.15$ & $830 \pm 95$ & $8.13 \pm 0.37$ & $34.6 \pm 1.0$ & $955 \pm 68$ & $5.33 \pm 0.22$ \\
\hline $99-164$ & & $29.9 \pm 1.51$ & $995 \pm 46$ & $7.50 \pm 0.60$ & $37.9 \pm 2.6$ & $1100 \pm 95$ & $5.93 \pm 0.24$ \\
\hline $00-7$ & & $25.1 \pm 1.35$ & $772 \pm 73$ & $7.67 \pm 0.96$ & $23.6 \pm 2.7$ & $745 \pm 110$ & $4.93 \pm 0.77$ \\
\hline $00-45$ & & $26.3 \pm 0.82$ & $840 \pm 63$ & $8.83 \pm 0.17$ & $29.5 \pm 0.26$ & $971 \pm 22$ & $4.50 \pm 0.40$ \\
\hline $00-59$ & & $26.8 \pm 1.90$ & $1010 \pm 100$ & $9.53 \pm 0.27$ & $29.7 \pm 2.2$ & $1060 \pm 58$ & $5.47 \pm 0.20$ \\
\hline \multirow[t]{3}{*}{$\mathrm{LSD}_{0.05}$} & & 10.2 & 228 & 1.12 & 6.2 & 161.4 & 0.80 \\
\hline & \multirow[b]{2}{*}{$\mathrm{df}$} & \multicolumn{2}{|c|}{ Antioxidant capacity } & \multicolumn{2}{|c|}{ Total soluble phenolics } & \multicolumn{2}{|c|}{ Total soluble solids } \\
\hline & & Mean s & $\mathrm{F}$ & Mean square & $\mathrm{F}$ & Mean square & $\mathrm{F}$ \\
\hline$\overline{\text { Harvest }(\mathrm{H})}$ & 1 & & $0.31^{\mathrm{Ns}}$ & 185181 & $12.8^{* *}$ & 549 & $1565^{* * * *}$ \\
\hline Cultivar (C) & 21 & 1237 & $2.22^{* *}$ & 1492175 & $4.91^{* * *}$ & 41.1 & $5.57^{* * *}$ \\
\hline $\mathrm{H} \times \mathrm{C}$ & 21 & 624 & $1.12^{\mathrm{Ns}}$ & 209006 & $0.69^{\mathrm{Ns}}$ & 27.7 & $3.75^{* * *}$ \\
\hline
\end{tabular}

zExpressed in Trolox equivalents (TE).

yTotal soluble phenolics measured by the Folin-Ciocalteu assay (gallic acid equivalents).

Ns, $*, * * * * *$ Nonsignificant or significant at $P<0.05,0.01$, or 0.001 , respectively.

antioxidant phytochemicals. Table 6 also describes the effects of cultivar, season, and year of harvest on the soluble solids and phytochemical levels of the nine selected winter-grown strawberries. Cultural practices and growing conditions were held constant but the mean air temperature during the development period for fruit harvested in 23 Jan. 2004 was higher than during the same period in $2003\left(14.5\right.$ vs. $\left.12.0^{\circ} \mathrm{C}\right)$, while the mean air temperature during the development period for fruit harvested in 27 Feb. 2004 was similar to that for the same period in 2003 $\left(16.2\right.$ vs. $\left.16.4^{\circ} \mathrm{C}\right)$. Average daily solar radiation was lower in 2004 than in $2003\left(608\right.$ and $592 \mu \mathrm{mol} \cdot \mathrm{m}^{-2} \cdot \mathrm{s}^{-1}$ for 2004 , compared to 640 and $672 \mu \mathrm{mol} \cdot \mathrm{m}^{-2} \cdot \mathrm{s}^{-1}$ for 2003$)$.

Fruit harvested in 2004 were found to have considerably lower total anthocyanin concentrations than those harvested in 2003 (Table 5), which corresponded to obvious color differences in informal visual observations. Fruit harvested on 23 Jan. 2003 had 2.2- to 3.5-fold higher total anthocyanin concentrations than fruit from 23 Jan. 2004, while fruit harvested on 27 Feb. 2003 had 1.7- to 2.8-fold higher total anthocyanin concentrations than fruit harvested on $27 \mathrm{Feb}$. 2004. 'Carmine' was a noted exception with consistently high anthocyanin levels in both 2003 and 2004. The trend for L-ascorbic acid was opposite of that observed for anthocyanins (Table 5) such that fruit harvested in 2004 had higher L-ascorbic acid levels (1.8- to 3.4-fold) than those harvested in 2003. 'Earlibrite' ranked among the highest for L-ascorbic acid concentration at the January harvest in both 2003 and 2004, but its February harvest concentrations were significantly lower. 'Carmine', 'Treasure', and the breeder selection 'FL 99-140' were the only genotypes for which harvest date had a significant effect on total soluble phenolics, and only for the 2004 season (Table 5). Production year was a variable that significantly influenced antioxidant capacity and total soluble phenolics levels, with 2004 fruit containing up to 3-fold higher total phenolics and 1.6- to 2.5-fold lower antioxidant capacity than 2003 fruit.

Differences between harvest dates for soluble solids were again observed in 2004 (Tables 5-6) with fruit harvested on 23 Jan. having higher soluble solids concentrations; however, the magnitude of difference between harvests was lower than in 2003 (1.4-fold). Harvest year did not affect the soluble solids concentration of January-harvested fruit, but did affect fruit harvested on $27 \mathrm{Feb}$. with an average of $5.0 \%$ soluble solids in 2003 compared to $6.6 \%$ soluble solids in 2004 . As in 2003 , the $\mathrm{pH}$ varied only slightly among genotypes ranging from $\mathrm{pH} 3.4$ to 3.8 and was not significantly affected by harvest date. 
Table 5. Effect of harvest time on soluble solids and phytochemical constituents of selected winter-grown strawberries harvested in 2004. Data are expressed on a fresh weight basis (mean $\pm \mathrm{se}$ ). Analysis of variance was also determined for the nine cultivars harvested in 2003.

\begin{tabular}{|c|c|c|c|c|c|c|}
\hline & \multicolumn{3}{|c|}{ January harvest (2004) } & \multicolumn{3}{|c|}{ February harvest (2004) } \\
\hline Cultivar & $\begin{array}{c}\text { Total soluble } \\
\text { solids } \\
(\%)\end{array}$ & $\begin{array}{c}\text { Total soluble } \\
\text { phenolics } \\
\left(\mathrm{mg} \cdot \mathrm{kg}^{-1}\right)\end{array}$ & $\begin{array}{c}\text { L-ascorbic } \\
\text { acid } \\
\left(\mathrm{mg} \cdot \mathrm{kg}^{-1}\right)\end{array}$ & $\begin{array}{c}\text { Total soluble } \\
\text { solids } \\
(\%)\end{array}$ & $\begin{array}{c}\text { Total soluble } \\
\text { phenolics } \\
\left(\mathrm{mg} \cdot \mathrm{kg}^{-1}\right)\end{array}$ & $\begin{array}{c}\text { L-ascorbic } \\
\text { acid } \\
\left(\mathrm{mg} \cdot \mathrm{kg}^{-1}\right)\end{array}$ \\
\hline Carmine & $8.73 \pm 0.17$ & $3230 \pm 84$ & $488 \pm 49$ & $6.57 \pm 0.12$ & $2590 \pm 64$ & $338 \pm 57$ \\
\hline Earlibrite & $9.80 \pm 0.10$ & $2580 \pm 230$ & $668 \pm 15$ & $7.57 \pm 0.09$ & $2680 \pm 174$ & $488 \pm$ \\
\hline Festival & $8.73 \pm 0.27$ & $2530 \pm 140$ & $536 \pm 4.0$ & $6.27 \pm 0.23$ & $2310 \pm 140$ & $410 \pm$ \\
\hline Sweet Charlie & $10.2 \pm 0.27$ & $2330 \pm 20$ & $445 \pm 22$ & $6.60 \pm 0.06$ & $2140 \pm 89$ & $495 \pm 74$ \\
\hline Treasure & $9.73 \pm 0.12$ & $2370 \pm 109$ & $657 \pm 35$ & $6.63 \pm 0.17$ & $2790 \pm 33$ & $410 \pm 45$ \\
\hline $95-269$ & $9.10 \pm 0.35$ & $2370 \pm 40$ & $486 \pm 7.0$ & $6.57 \pm 0.09$ & $2710 \pm 152$ & $609 \pm 24$ \\
\hline $97-39$ & $8.57 \pm 0.27$ & $2530 \pm 90$ & $433 \pm 31$ & $6.53 \pm 0.20$ & $2400 \pm 270$ & $542 \pm 35$ \\
\hline $99-140$ & $9.60 \pm 0.35$ & $2610 \pm 53$ & $624 \pm 65$ & $7.77 \pm 0.07$ & $2140 \pm 50$ & $449 \pm 45$ \\
\hline $99-164$ & $10.0 \pm 0.09$ & $2430 \pm 28$ & $443 \pm 26$ & $5.23 \pm 0.07$ & $2390 \pm 146$ & $489 \pm 13$ \\
\hline $\mathrm{LSD}_{0.05}$ & 0.72 & 319 & 101 & 0.40 & 422 & 138 \\
\hline
\end{tabular}

\begin{tabular}{|c|c|c|c|c|}
\hline \multirow[b]{2}{*}{ Cultivar } & \multicolumn{2}{|c|}{ January harvest (2004) } & \multicolumn{2}{|c|}{ February harvest (2004) } \\
\hline & $\begin{array}{l}\text { Antioxidant } \\
\text { capacity } \\
\left(\mu \mathrm{M} \cdot \mathrm{g}^{-1} \mathrm{TE}\right)\end{array}$ & $\begin{array}{c}\text { Total } \\
\text { anthocyanins }^{\mathrm{x}} \\
\left(\mathrm{mg} \cdot \mathrm{kg}^{-1}\right)\end{array}$ & $\begin{array}{c}\text { Antioxidant } \\
\text { capacity } \\
\left(\mu \mathrm{M} \cdot \mathrm{g}^{-1} \mathrm{TE}\right)\end{array}$ & $\begin{array}{c}\text { Total } \\
\text { anthocyanins } \\
\left(\mathrm{mg} \cdot \mathrm{kg}^{-1}\right)\end{array}$ \\
\hline Carmine & $17.2 \pm 0.70$ & $120 \pm 4.7$ & $19.2 \pm 2.59$ & $219 \pm 8.2$ \\
\hline Earlibrite & $16.4 \pm 1.8$ & $98 \pm 1.0$ & $18.9 \pm 2.11$ & $182 \pm 15.1$ \\
\hline Festival & $16.0 \pm 0.87$ & $121 \pm 8.9$ & $18.4 \pm 0.88$ & $204 \pm 6.2$ \\
\hline Sweet Charlie & $15.5 \pm 0.28$ & $99 \pm 2.0$ & $15.0 \pm 0.96$ & $127 \pm 2.2$ \\
\hline Treasure & $15.9 \pm 1.9$ & $123 \pm 8.8$ & $22.3 \pm 1.36$ & $222 \pm 4.7$ \\
\hline $95-269$ & $12.9 \pm 0.60$ & $74 \pm 1.6$ & $19.9 \pm 1.70$ & $161 \pm 6.9$ \\
\hline $97-39$ & $13.8 \pm 1.4$ & $125 \pm 4.9$ & $16.4 \pm 1.88$ & $138 \pm 12.8$ \\
\hline $99-140$ & $16.1 \pm 0.52$ & $99 \pm 4.4$ & $18.2 \pm 0.65$ & $177 \pm 1.6$ \\
\hline $99-164$ & $15.4 \pm 0.90$ & $137 \pm 2.7$ & $16.8 \pm 2.12$ & $182 \pm 13.3$ \\
\hline $\mathrm{LSD}_{0.05}$ & 3.38 & 15.3 & 5.05 & 27.1 \\
\hline
\end{tabular}

\begin{tabular}{|c|c|c|c|c|c|c|c|c|c|c|c|}
\hline & \multirow[b]{2}{*}{ df } & \multicolumn{2}{|c|}{ Total soluble solids } & \multicolumn{2}{|c|}{ Total soluble phenolics } & \multicolumn{2}{|c|}{ L-ascorbic acid } & \multicolumn{2}{|c|}{ Antioxidant capacity } & \multicolumn{2}{|c|}{ Total anthocyanins } \\
\hline & & Mean square & $\mathrm{F}$ & Mean square & $\mathrm{F}$ & Mean square & $\mathrm{F}$ & Mean square & $\mathrm{F}$ & Mean square & $\mathrm{F}$ \\
\hline Harvest $(\mathrm{H})$ & 1 & 101 & $892^{\mathrm{Ns}}$ & 29962 & $2.41^{\mathrm{Ns}}$ & 50068 & $10.0^{* *}$ & 112.8 & $17.9^{* * *}$ & 63187923 & $383^{* * *}$ \\
\hline Cultivar (C) & 8 & 11.1 & $12.1^{* *}$ & 473412 & $4.57^{* * * *}$ & 127664 & $3.19^{* *}$ & 83.3 & $1.66^{\mathrm{Ns}}$ & 23383 & $17.7^{\mathrm{ss}}$ \\
\hline $\mathrm{H} \times \mathrm{C}$ & 8 & 10.6 & $1.12^{\mathrm{Ns}}$ & 375227 & $3.78^{* * * *}$ & 240551 & $6.81^{* * * *}$ & 66.9 & $1.33^{\mathrm{NS}}$ & 11976 & $9.08^{\mathrm{Ns}}$ \\
\hline
\end{tabular}

${ }^{2}$ Total soluble phenolics measured by the Folin-Ciocalteu assay (gallic acid equivalents).

yExpressed in Trolox equivalents (TE).

xTotal anthocyanin content was quantified with the $\mathrm{pH}$-differential, spectrophotometric assay (pelargonidin 3-glucoside equivalents).

Ns, ${ }^{*}, * * * * *$ Nonsignificant or significant at $P<0.05,0.01$, or 0.001 , respectively.

Table 6. Analysis of variance for soluble solids and phytochemical constituents of selected winter-grown strawberries (Fragaria $\times a n a n a s s a)$ harvested in 2003 and 2004.

\begin{tabular}{|c|c|c|c|c|c|c|c|c|c|c|c|}
\hline \multirow[b]{2}{*}{ Variable } & \multirow[b]{2}{*}{$\mathrm{df}$} & \multicolumn{2}{|c|}{$\begin{array}{c}\text { Total soluble } \\
\text { solids (\%) }\end{array}$} & \multicolumn{2}{|c|}{$\begin{array}{c}\text { Total } \\
\text { anthocyanins }\end{array}$} & \multicolumn{2}{|c|}{$\begin{array}{l}\text { L-ascorbic } \\
\text { acid }\end{array}$} & \multicolumn{2}{|c|}{$\begin{array}{l}\text { Antioxidant } \\
\text { capacity }\end{array}$} & \multicolumn{2}{|c|}{$\begin{array}{c}\text { Total soluble } \\
\text { phenolics }\end{array}$} \\
\hline & & $\begin{array}{l}\text { Mean } \\
\text { square }\end{array}$ & $\mathrm{F}$ & $\begin{array}{l}\text { Mean } \\
\text { square }\end{array}$ & $\mathrm{F}$ & $\begin{array}{l}\text { Mean } \\
\text { square }\end{array}$ & $\mathrm{F}$ & $\begin{array}{l}\text { Mean } \\
\text { square }\end{array}$ & $\mathrm{F}$ & $\begin{array}{l}\text { Mean } \\
\text { square }\end{array}$ & $\mathrm{F}$ \\
\hline Season $(\mathrm{S})$ & 1 & 23.4 & $142^{* * *}$ & 1343977 & $1513^{* * * *}$ & 1931270 & $652^{* * * *}$ & 4623 & $596^{* * * *}$ & 63570806 & $2177^{* * * *}$ \\
\hline Year $(Y)$ & 1 & 317 & $1931^{\text {*** }}$ & 274478 & $309^{* * * *}$ & 157079 & $53.1^{* *}$ & 121 & $15.6^{* * * *}$ & 3790 & $0.13^{\text {ss }}$ \\
\hline $\mathrm{S} \times \mathrm{Y}$ & 1 & 12.5 & $75.9^{* * *}$ & 28363 & $31.9^{* * *}$ & 6382 & $2.16^{\mathrm{Ns}}$ & 16.2 & $2.09^{\mathrm{Ns}}$ & 175224 & $6.00^{*}$ \\
\hline Cultivar (C) & 8 & 12.5 & $9.54^{* * * *}$ & 177709 & $25.0^{* * *}$ & 80137 & $3.38^{* *}$ & 216 & $3.48^{* *}$ & 2013674 & $8.62^{\text {*** }}$ \\
\hline $\mathrm{S} \times \mathrm{C}$ & 8 & 9.36 & $7.12^{* * * *}$ & 69833 & $9.83^{* * * *}$ & 70640 & $2.98^{* *}$ & 175 & $2.82^{* *}$ & 345096 & $1.48^{\mathrm{Ns}}$ \\
\hline $\mathrm{Y} \times \mathrm{C}$ & 8 & 6.48 & $4.93^{\text {*** }}$ & 35299 & $4.97^{* * * *}$ & 194876 & $8.23^{\text {**** }}$ & 77.6 & $1.25^{\mathrm{NS}}$ & 476630 & $2.04^{\mathrm{Ns}}$ \\
\hline $\mathrm{S} \times \mathrm{Y} \times \mathrm{C}$ & 8 & 23.1 & $17.6^{* * *}$ & 46217 & $6.50^{* * * *}$ & 89890 & $3.80^{\text {**** }}$ & 201 & $3.23^{* *}$ & 1048729 & $4.49^{* * *}$ \\
\hline
\end{tabular}

Ns, ***,***Nonsignificant or significant at $P \leq 0.05,0.01$, or 0.001 , respectively. 


\section{Conclusions}

This study demonstrated significant differences in soluble solids and phytochemical concentrations that existed among 22 strawberry genotypes grown in a winter hill production system. In general, fruit harvested on $27 \mathrm{Feb}$. had higher levels of anthocyanin and phenolic compounds and lower levels of ascorbic acid and soluble solids than January-harvested fruit. These chemical differences resulted in fruit with lower sugar and flavor attributes in the February fruit in two consecutive production years. Although anthocyanin, ascorbic acid, and soluble solids content varied significantly between harvests, the antioxidant capacity of fruit was not significantly affected by harvest date. Large variations in the concentrations of phytochemical compounds were also observed between production years, and may be related to yearly variation in solar radiation and air temperature since these are factors known to impact phytochemical biosynthesis.

Among the commercial cultivars, 'Carmine' had relatively high phytochemical content across harvest dates and years and the breeder selection 'FL 99-117' appeared to be a promising selection in terms of both soluble solids and antioxidant phytochemicals. The results from this study will become an important part of the selection process in the University of Florida breeding program by identifying new genotypes with enhanced consumer acceptability, high concentrations of antioxidant phytochemicals, and steady yields of fruit during the winter.

\section{Literature Cited}

Amakura, Y., Y. Umino, S. Tsuji, and Y. Tonogai. 2000. Influence of jam processing on the radical scavenging activity and phenolic content in berries. J. Agr. Food Chem. 48:6292-6297.

Anderson, P.C. and D.W. Gorbet. 2002. Influence of year and planting date on fatty acid chemistry of high oleic acid and normal peanut genotypes. J. Agr. Food Chem. 50:1298-1305.

Asami, D.K., Y.J. Hong, D.M. Barrett, and A.E. Mitchell. 2003. Comparison of the total phenolic and ascorbic acid content of freeze-dried and air-dried marionberry, strawberry, and corn grown using conventional, organic, and sustainable agricultural practices. J. Agr. Food Chem. 51:1237-1241.

Ayala-Zavala, J.F., S.Y. Wang, C.Y. Wang, and G.A. González-Aguilar. 2004. Effect of storage temperatures on antioxidant capacity and aroma compounds in strawberry fruit. Lebens-Wissensschaft Technol. 37:687-695.

Bridle, P. and C. García-Viguera. 1997. Analysis of anthocyanins in strawberries and elderberries. A comparison of capillary zone electrophoresis and HPLC. Food Chem. 59:299-304.

Chandler, C.K., M. Herrington, and A. Slade. 2003. Effect of harvest date on soluble solids and titratable acidity in fruit of strawberry grown in a winter, annual hill production system. Acta Hort. 626:353-354.

Cordenunsi, B.R., M.I. Genovese, J.R. Oliveira do Nascimento, N.M. Hassimotto, R.J. dos Santos, and F.M. Lajolo. 2005. Effects of temperature on the chemical composition and antioxidant activity of three strawberry cultivars. Food Chem. 91:113-121.

Darbellay, C., C. Carlen, R. Azodanlou, and J.C. Villettaz. 2002. Measurement of the organoleptic quality of strawberries. Acta Hort. 567:819-822.

Gökmen, V., N. Kahraman, N. Demir, and J. Acar. 2000. Enzymatically validated liquid chromatographatic method for the determination of ascorbic and dehydroascorbic acids in fruit and vegetables. J. Chromatography A. 881:309-316.

Häkkinen, S., M. Heinonen, S. Kärenlampi, H. Mykkänen, J. Ruuskanen, and R. Törrönen. 1999. Screening of selected flavonoids and phenolic acids in 19 berries. Food Res. Intl. 32:345-353.

Hong, V. and R. Wrolstad. 1990. Characterization of anthocyanin-containing colorants and fruit juices by HPLC/ photodiode array detection. J. Agr. Food Chem. 38:698-708.

Kahkonen, M.P., A.I. Hopia, and M. Heinonen. 2001. Berry phenolics and their antioxidant activity. J. Agr. Food Chem. 49:4076-4082.

Kalt, W., C.F. Forney, A. Martin, and R.L Prior. 1999. Antioxidant capacity, vitamin $\mathrm{C}$, phenolics, and anthocyanins after fresh storage of small fruits. J. Agr. Food Chem. 47:4638-4644.
Kosar, M., E. Kafkas, S. Paydas, and K.H.C. Baser. 2004. Phenolic composition of strawberry genotypes at different maturation stages. J. Agr. Food Chem. 52:1586-1589.

Linko, R., J. Karppa, H. Kallio, and S. Ahtonen. 1983. Anthocyanin contents of crowberry and crowberry juice. Lebens-Wissensschaft Technol. 16:343-345.

Maynard, D.N. and S.M. Olson (eds.). 2000. Vegetable production guide for Florida. Univ. Fla., Fla. Coop. Ext. Serv. Circ. SP 170.

Meyer, A.S., M. Heinonen, and E.N. Frankel. 1998. Antioxidant interactions of catechin, cyanidin, caffeic acid, quercetin, and ellagic acid on human LDL oxidation. Food Chem. 861:71-75.

Meyers, K.J., C.B. Watkins, M.P.Pritts, and R.H.Liu. 2003. Antioxidant and antiproliferative activities of strawberries. J. Agr. Food Chem. 51:6887-6892.

Olsson, M.E., J. Ekvall, K. Gustavsson, J. Nilsson, D. Pillai, I. Sjöholm, U. Svensson, B. Åkesson, and M.G.L. Nyman. 2004. Antioxidants, low molecular weight carbohydrates, and total antioxidant capacity in strawberries (Fragaria $\times$ ananassa): Effects of cultivar, ripening, and storage. J. Agr. Food Chem. 52:2490-2498.

Perez, A.G., R. Olias, J. Espada, J.M. Olias, and C. Sanz. 1997. Rapid determination of sugars, nonvolatile acids, and ascorbic acid in strawberry and other fruits. J. Agr. Food Chem. 45:3545-3549.

Pinelo, M., L. Manzocco, M.J. Nunez, and M.C. Nicoli. 2004. Interaction among phenols in food fortification: Negative synergism on antioxidant capacity. J. Agr. Food Chem. 52:1177-1180.

Rice-Evans, C.A., N.J. Miller, and G. Paganga. 1996. Structure-antioxidant activity relationships of flavonoids and phenolic acids. Free Radical Biol. Medicine 20:933-956.

Sanli, N. , G. Fonrodona, D. Barrón, G. Özkan, and J. Barbosa. 2002. Prediction of chromatographic retention, $\mathrm{pKa}$ values and optimization of the separation of polyphenolic acids in strawberries. J. Chromatography A. 975:299-309.

Sekher, A.P., T.S. Chan, P.J. O'Brien, and C.A. Rice-Evans. 2001. Flavonoid B-ring chemistry and antioxidant activity: Fast reaction kinetics. Biochem. Biophys. Res. Comm. 5:1161-1168.

Skrede, G., R.E. Wrolstad, and R.W. Durst, 2000. Changes in anthocyanins and polyphenolics during juice processing of highbush blueberries (Vaccinium corymbosum L.). J. Food Sci. 65:357-364.

Talcott, S.T., C.H. Brenes, and L.R. Howard. 2000. Contribution of periderm material and blanching time to the quality of pasteurized peach puree. J. Agr. Food Chem. 48:4590-4596.

Talcott, S.T. and J.H. Lee. 2002. Ellagic acid and flavonoid antioxidant content of muscadine wine and juice. J. Agr. Food Chem. 50:3186-3192.

Talcott, S.T., S.S. Percival, J. Pitter-Moore, and C. Celoria. 2003. Phytochemical composition and antioxidant stability of fortified yellow passion fruit (Passiflora edulis). J. Agr. Food Chem. 51:935-941.

U.S. Dept. of Agriculture. 2004. Economics, statistics and market information system, non-citrus fruit and nuts. USDA, Natl. Agr. Stat. Serv. 1 June 2004. $<$ http://www.usda.mannlib.cornell.edu/>.

U.S. Naval Observatory. 2004. Sun or moon rise/set table for one year. U.S. Naval Observatory, Astronomical Applications Dept. 12 Dec. 2004. <http:// aa.usno.navy.mil/data/docs/RS_OneYear.html>.

University of Florida. 2004. Florida automated weather network, search database. Univ. of Florida, Inst. Food Agr. Sci. 12 Dec. 2004. <http://fawn. ifas.ufl.edu/scripts/search/costom.idc >.

Wang, H., G. Cao, and R.L. Prior. 1996. Total antioxidant capacity of fruits. J. Agr. Food Chem. 44:701-705.

Wang, S.Y. and M.J. Camp. 2000. Temperatures after bloom affect plant growth and fruit quality of strawberry. Scientia Hort. 85:183-199.

Wang, S.Y. and H.S. Lin. 2000a. Antioxidant activity in fruits and leaves of blackberry, raspberry, and strawberry varies with cultivar and developmental stage. J. Agr. Food Chem. 48:140-146.

Wang, S.Y. and H.S. Lin. 2000b. Antioxidant activity in fruits and leaves of blackberry, raspberry, and strawberry varies with cultivar and developmental stage. J. Agr. Food Chem. 48:140-146.

Wang, S.Y. and W. Zheng. 2001. Effect of plant growth temperature on antioxidant capacity in strawberry. J. Agr. Food Chem. 49:4977-4982.

Wang, S.Y., W. Zheng, and G.J. Galletta. 2002. Cultural system affects fruit quality and antioxidant capacity in strawberries. J. Agr. Food Chem. 50:6534-6542.

Wrolstad, R.E. 1976. Color and pigment analysis in fruit products. Oregon State Univ. Bul. 624.

Zafrilla, P., F. Ferreres, and F.A. Tomas-Barberán. 2001. Effect of processing and storage on the antioxidant ellagic acid derivatives and flavonoids of red raspberry (Rubus idaeus) jams. J. Agr. Food Chem. 49:3651-3655. 